\title{
Abandonment of terminally ill patients in the Byzantine era. An ancient tradition?
}

John Lascaratos, Effie Poulakou-Rebelakou and Spyros Marketos National University of Athens, National Centre of Health and National University of Athens, respectively

\begin{abstract}
Our research on the texts of the Byzantine historians and chroniclers revealed an apparently curious phenomenon, namely, the abandonment of terminally ill emperors by their physicians when the latter realised that they could not offer any further treatment. This attitude tallies with the mentality of the ancient Greek physicians, who even in Hippocratic times thought the treatment and care of the terminally ill to be a challenge to nature and hubris to the gods. Nevertheless, it is a very curious attitude in the light of the concepts of the Christian Byzantine physicians who, according to the doctrines of the Christian religion, should have been imbued with the spirit of philanthropy and love for their fellowmen. The meticulous analysis of three examples of abandonment of Byzantine emperors, and especially that of Alexius I Comnenus, by their physicians reveals that this custom, following ancient pagan ethics, in those times took on a ritualised form without any significant or real content.
\end{abstract}

(Fournal of Medical Ethics 1999;25:254-258)

Keywords: Byzantine care; caring ethics; terminally ill patients, tradition

\section{Introduction}

End-of-life decisions remain a complicated problem in the relationships between physicians and the patient's family, with social and legal consequences which today face all civilised societies. ${ }^{1}$ The attitude of doctors to euthanasia in particular seems to have occupied and troubled societies from antiquity, as the Hippocratic Oath and the concepts of the earlier Pythagorians indicate. Although the Hippocratic Oath, perhaps following the school of Pythagoras, ${ }^{2}$ is categorically against every idea of euthanasia, it was thought unethical for a doctor in ancient times to treat a patient with a deadly disease, for this challenged nature and constituted hubris against the gods, so the doctor would risk paying the penalty of divine nemesis. This concept is found even in some Hippocratic texts but cannot be justified in societies deeply influenced by the Christian religion where the physician ought to give love to his fellowman (anthropos) rather than to his art (techne) and to treat all his patients irrespective of class, status of wealth and ability to pay. In these societies thie doctors' altruistic duty apparently involves the compassionate care and consolation of the termiv nally ill. ${ }^{3}$ For these reasons one can nowadays bf surprised to find, on studying the Byzantine histo? rians and chroniclers, some cases of abandonment of dying emperors by their physicians who realise that they could not offer any further medica treatment. The meaning of abandonment in thess texts seems to have been exclusively restricted to medical treatment when no further scientific helf was possible and only philanthropic and Christia compassion remained to be offered. As is self evt dent, Byzantine medicine - basically philanthrop: because it was a product of Christian philosophy气 could not permit this custom of abandonmen $\vec{E}$ For this reason, these cases referred to by reliable Byzantine writers appear at first sight unusual and inexplicable because they cannot be understood on the basis of the Christian thinking on and atti tudes towards the relationship between patients and physicians. On the contrary, in accordance with the way of thinking of Byzantine medicine, would seem most rational for physicians to be in attendance on the patient and offer medica assistance until the latter's death. Before, howeves interpreting this curious custom, we shoulg examine the cases which are referred to and described by Byzantine writers.

\section{The information provided by the Byzantine texts}

1) A NEAR FATAL ILLNESS OF JUSTINIAN THE GREAT (527-565)

During the great epidemic which struck the empire in the age of Justinian, the well-known "Justinianic Plague", the emperor himself be came seriously ill. As evidenced by the historiaf Procopius: "The bubonic area of his body swelle up". ${ }^{5}$ The same contemporary historian notes iro another of his works ${ }^{6}$ that:

"This epidemic struck the population of Byzano tium and it then happened that Justinian was ser 
ously afflicted to the extent that a rumour was spread that he was dead".

According to the historian, this rumour had political implications because some were thinking of the succession to the throne and this provoked the rage and immediate reaction of his wife, Theodora, who after the unexpected recovery of the emperor punished harshly the would-be pretenders to the throne. ${ }^{7}$ More information is provided by Procopius in his third work, ${ }^{8}$ in which he writes:

"When Justinian fell seriously ill and gave the impression that he was about to die he had been abandoned by his physicians because he was considered to be already among the dead. Then the saints Cosmas and Damien appeared before him and, paradoxically, saved him and his health was restored. The emperor, to express his gratitude, established a great and magnificent church in their honour at the end of the Golden Horn in Constantinople. Those who had lost all hope, as a result of unsuccessful medical treatment by physicians, took to the boats in the gulf and came to this church, the only hope remaining for them."

The abandonment of the emperor by his physicians when they realised the hopelessness of his case is clearly evident from this extract. It must be pointed out that the physicians of the palace, the so called "actuarii", had the confidence of the emperor and his entourage. Furthermore, the dynamic Empress Theodora supervised and controlled the medical staff, as she did all other members of the court and no Byzantine writer suggested there was any hint of political motivation behind the physicians' act of abandonment.

\section{2) THE FATAL DISEASE OF ALEXIUS I COMNENUS (1081-1118)}

On the question of the aetiology of the fatal disease of Alexius I Comnenus many opinions and interpretations have been expressed. The first was that of Verdun, the Jesuit physician of Hôtel Dieu, Paris, who maintained that the emperor's death was due to complications of sarcoma of the shoulder and thorax. ${ }^{9}$ This opinion was contradicted by Professor K Alexandrides who held the opinion that the emperor's disease was the result of heart failure due to a previous acute myocardial infarction which manifested itself six months before his death while gout co-existed. ${ }^{10}$ It is known that such heart attacks are frequent in this latter condition because of sclerosis of the coronary arteries. ${ }^{11}$ This opinion became accepted by later writers such as J Körbler ${ }^{12}$ and K-H Leven. ${ }^{13}$
During the last stages of the emperor's disease, physicians made superhuman attempts to save him. At repeated medical councils his daughter, the well-known historian Anna Comnena, who had also studied medicine, presided. Comnena provides us with the most valuable details of her father's disease. In her text it is apparent that the dietetic therapy, the drugs, the phlebotomy, the transfer of Alexius to the Maggana (another palace) for the change of air and finally the cauterisation of the stomach did not help the emperor but that, on the contrary, he remained on the verge of death. On the morning of 15 August 1118:

"some physicians rubbed the head of the Emperor with myrrh and left for their homes, not because they had an urgent reason but because they knew that fatal danger was approaching the Emperor".

Comnena names three leading physicians among those who had left, Nicholas Callicles, Michael Pantechnes and Michael the Eunuch. Comnena also says that several hours later some physicians returned to the emperor's bedside and checked his pulse, trying to encourage the empress, who was in a dreadful psychological state. ${ }^{14}$

Another contemporary chronicler, John Zonaras, ${ }^{15}$ also refers to the last hours of the emperor, writing that:

"All day he was in death throes and in the afternoon he died at about seventy years of age and his end was in complete contrast to his happy reign, because he was abandoned by almost all his physicians and there were not even some to give him a final bath and to adorn his body in a way suitable for a king or even to provide him with the appropriate royal funeral."

These criticisms made by Zonaras must be carefully examined because he was prejudiced due to a personal clash with Anna Comnena who had removed him from the royal entourage ${ }^{16}$ and he obviously wanted to apportion blame to her and her brother, John, the heir to the throne, for failing to look after their dying father. In any case, independently of Zonaras's interpretation, which scarcely hides accusations against Alexius's children, he also reveals that the emperor was abandoned by his physicians.

3) THE DISEASE OF ANDRONICUS III PALAEOLOGUS THE YOUNGER (1328-1341)

In the last twenty years of his life Andronicus III presented crises of the enlargement of the spleen and febrile attacks. His disease, probably 
malaria, ${ }^{17}$ caused the emperor to go into a coma and to die.

Cantacuzenus describes an episode of the disease during the first years of its appearance (c1329). This was obviously a cerebral form of the disease, beginning as an acute stroke, ${ }^{18}$ which in the evening of the third day intensified, when signs of approaching death appeared. From the text of Cantacuzenus, it appears that the emperor remained without any physician all night but unexpectedly recovered and asked for water from the spring of the Monastery of the Holy Mother. In the morning the physicians came and the leader of this group took his pulse and, amazed, discerned that there was a light pulse, which he attributed to a miracle. ${ }^{19}$

\section{Discussion}

From the three cases described above, and especially from the second, which is described by the reliable and well-educated historian Anna Comnena, it is clear that in Byzantium the abandonment by physicians of a patient at the stage just prior to death was a common custom when no medical means were believed available to save the patient. From Anna Comnena's text ${ }^{20}$ this desertion appears to have been ceremonial. This derives from the fact that only some physicians withdrew from the emperor after they had applied myrrh to his head, returning after a few hours. Such events and the natural way Anna Comnena narrates them, stressing that the physicians left because they had no more scientific services to offer, lead us to the conclusion that this abandonment was the usual ceremony - normal behaviour - in such desperate cases. According to Anna Comnena's detailed narration, the physicians withdrew after the rubbing of the head with myrrh and returned after a few hours to offer their compassionate assistance (that is, to show their solidarity with the empress, since they were in no way able to proffer medical help to their patient).$^{20}$ It is obvious that the abandonment, even in its ritual form, does not tally with modern medical ethics which usually imposes on physicians the obligation to offer their scientific help to a patient even in hopeless cases. ${ }^{21}$

Deichgräber, attempting to interpret this ancient custom, maintains that the withdrawal of the physicians in desperate cases accords with the ideas of the Hippocratic Oath and follows an ancient tradition. ${ }^{22}$ However, study of the Hippocratic Oath does not support such an idea, ${ }^{23}$ but nevertheless the origins of this withdrawal must be sought in pre-Christian times. Plato, ${ }^{24}$ in The Republic says that Asclepius makes no attempt to prolong an unhappy life in the case of those who are seriously ill and furthermore states that Pindar and the tragedians maintain that "the son of Apollo, Asclepius", once "was bribed by a large fee to cure a rich man who was at death's doo and blasted by a thunderbolt in consequence".

In the treatises of the Corpus Hippocraticum the belief is supported that physicians must prudent in the application of their treatments an it is stressed that "where there is love for man there is also love for the art of medicine" Furthermore, an aphorism of Hippocrates ${ }^{26}$ refe $\overrightarrow{9}$ to the fact that "for extreme diseases, extreme methods of cure, as to restriction, are mos suitable". The significance of this is that difficult cases of disease an aggressive form \&f treatment must be applied. On the other hand from some other ideas springs the whole treatise of the Corpus Hippocraticum, The Art, ${ }^{27}$ which $\mathcal{O N}_{\$}$ not one of Hippocrates's works of genius. The author of the work writes ${ }^{28}$ :

"First I will define what I conceive medicine to bबे. In general terms, it is to do away with the suffe $\bar{E}$ ings of the sick, to lessen the violence of their di@ eases, and to refuse to treat those who are overmastered by their diseases, realizing that such cases medicine is powerless".

In the same work the idea is presented that the ag of medicine cannot treat every illness because there are limits which cannot be overcome. In arts when the instruments are lacking the work stops, as the unknown Hippocratic author sa㞔 characteristically. ${ }^{29}$ Thus, continues the write medicine must offer its assistance in treatment bọt must equally prudently avoid care of patien when their diseases are untreatable. ${ }^{30}$ Conse quently it was thought to be in some way egoist for the ancient physician to believe that he couff treat the patients who were already condemned die and any such endeavour was supposed to hubris against the gods. ${ }^{31}$ In these circumstance and when it was difficult to reach a prognosis and discern what illness was treatable and what was untreatable, it remained the duty of the physiciang to decide whether to undertake the treatment not. ${ }^{32}$

However, particularly in Byzantium, physiciarฐ would not have been able to refuse their scientiffe help to patients even if they had reached the cone clusion that a case was untreatable. This because they believed that in many instance patients could be treated with the help of God, a $\$$ for example, in the above-mentioned case Andronicus, where the physician, without hesitaf tion, attributed the emperor's recovery to divire intervention. Further, in the case of Justinian's if ness, which had occurred several centuries before 
the recovery of the emperor was attributed by Justinian himself and his entourage to a miracle. These two instances, but also a whole series of similar cases, indicate that during the times of the Byzantine Empire it was a common belief that the possibility of divine intervention existed until the last stages of a disease. On the basis of these principles, the Christian physicians would never have been able to confront any case as hopeless because they would always have retained the hope that God could assist their work until the last moment. Some ideas, influenced both by the ideas of the Hippocratic treatise, The Art, and the Byzantine mentality, can be found in the work, Epitome, by the Byzantine physician Paul of Aegina (7th century). In his sixth book, when he refers ${ }^{33}$ to the cases of perforation by an arrow of vital organs of the body, such as heart, lungs, brain and so on and where already the signs of death have appeared, he advises the surgeons not to operate, because apart from the fact that they will not offer any benefit, they will give the ignorant the pretext to ridicule them, an idea deriving from the above-mentioned Hippocratic treatise. ${ }^{34}$ On the other hand, if the result of the operation seems unpredictable, the surgeon must make the patient aware of the possible danger and then proceed to the operation because, as Paul of Aegina concludes, ${ }^{35}$ in many patients, despite the fact that in these operations a part of the liver or peritoneum or all of the womb was removed the patient was finally saved.

Consequently, we can provide the explanation for abandonment, curious in the light of Byzantine ethics, that it followed a tradition from preChristian times which survived even in some texts of the Corpus Hippocraticum, and reached Byzantine times, as did many other beliefs of the Hippocratic ethos. ${ }^{36}$ It is clear, therefore, that in Byzantium this pagan custom was influenced by Christian ethics and, as appears from the excellent description of Anna Comnena, took on a ritual form.

\section{Conclusion}

From the information obtained from Byzantine historians and chroniclers and especially from Anna Comnena's text, it can be concluded that the abandonment of terminally ill patients by their physicians in Byzantine times (324-1453 AD), at first sight inexplicable because it seems totally contrary to the philosophy of charitable and Christian Byzantine medicine, followed an ancient pre-Christian tradition. According to this, medicine had prudently to avoid care of patients when their diseases were untreatable, because it constituted hubris against the gods. These very early ideas seem to have had an influence on some treatises of the Corpus Hippocraticum and especially on the treatise, The Art. Based on certain information provided by the historian Anna Comnena, we believe that this withdrawal of physicians in all probability represents the remnants of a pagan custom, which, under the influence of Christian ideas, took on no more than a ritual form without real content.

Fohn G Lascaratos, MD, PhD(Hist), is Assistant Professor of the Department of History and Philosophy of Medicine, School of Medicine, National University of Athens and a member of the International Hippocratic Foundation of Kos. Effie PoulakouRebelakou, MD, is Registrar of the National Centre of Health of Spata, a Philologist and a member of the International Hippocratic Foundation of Kos. Spyros $G$ Marketos, MD, is Professor and Chairman of the Department of History and Philosophy of Medicine, School of Medicine, National University of Athens, Honorary President of the International Society of the Humanistic-Neo-Hippocratic Medicine and the International Hippocratic Foundation of Kos, VicePresident of the International Society of the History of Medicine and President-elect of the Executive Committee of the European Society for Philosophy of Medicine and Health Care. Address for correspondence and reprint requests: Dr fohn Lascaratos, $M D$, PhD, Hippocratous 164 B st, Athens 11471, Greece.

\section{References}

1 McLean S. End-of-life decisions and the law. Fournal of Medical Ethics 1996;22:261-2.

2 Temkin O, Temkin CL. Ancient medicine. Selected papers of Ludwing Edelstein. Baltimore: The Johns Hopkins Press, 1967: 7-63.

3 Bradshaw A. Yes! There is an ethics of care: an answer for Peter Allmark. Fournal of Medical Ethics 1996;22:8-12.

4 Allen P. The "Justinianic" plague. Byzantion 1979;49:5-20.

5 Wirth G, ed. Procopii Caesarensis opera omnia. De bello Persico [vol I]. Lipsiae: BTeubner, 1962: 259.

6 Wirth G, ed. Procopii Caesarensis opera omnia. Historia arcana [vol III]. Lipsiae: BTeubner, $1963: 24$.

7 See reference 6: 25 .

8 Wirth G, ed. Procopii Caesarensis opera omnia. De aedificiis [vol IV]. Lipsiae : BTeubner, $1964: 30$.

9 Leib B, ed. Anne Comnène, Alexiade [vol III]. Paris : Les Belles Lettres, $1989: 230-41$.

10 Alexandrides K. Über die Krankheiten des Kaisers Alexios I Komnenos. Byzantinische Zeitscrift 1962;5:68-75.

11 See reference 10:74.

12 Körbler J. Einige Beiträge zur Geschichte der Krebskrankheit in Byzanz (Die Ärzte - Der Kaiser - Die Prinzessin). Janus 1971;58:101-11

13 Leven K-H. Der Tod des Kaisers Alexios I Komnenos. XXX Congrès International d'Histoire de la Médecine. Actes Proceedings, 1986: 896-904.

14 See reference $9: 230-41$

15 Büttner - Wobst T, ed. Ioannes Zonarae, epitomae [vol III]. Bonnae: Corpus Scriptorum Historiae Byzantinae, 1897 :764.

16 Hunger H. Byzantine literature [vol II]. Athens: Cultural Foundation of the National Bank, 1992:246-7.

17 Lascaratos J. The fatal disease of the Byzantine Emperor Andronicus III Palaeologus (1328-1341 AD). Fournal of the Royal Society of Medicine 1997;90:106-9.

18 Schopen L, ed. Ioannis Cantacuzeni eximperatoris historiarum libri iv [ vol I]. Bonnae: Corpus Scriptorum Historiae Byzantinae, 1828: 391-411

19 See reference $18: 410-11$ 
20 See reference 9: 236-9.

21 See reference 1: 261 .

22 See reference 13: 899 .

23 Prioreschi P. A history of medicine [vol 2]. Lewiston, New York, USA: The Edwin Mellen Press, 1994: 361-93.

24 Lee D. Plato, The Republic. London: Penguin Books, 1987: 171.

25 Deichgräber K. Die ärztliche Standesethik des Hippokratischen Eides. Quellen und Studien zur Geschichte der Naturwissenschaften und der Medizin 1933;3:79-99.

26 Adams F. The genuine works of Hippocrates. Huntington, New York, USA: R E Krieger, 1972: 293.

27 Jones WHS. Hippocrates [vol II]. London: The Loeb Classical Library, 1981: 190-217.
28 See reference $27: 192-3$.

29 See reference $27: 212-3$.

30 See reference 27: 216-7.

31 Schadewaldt H. Arzt und Patient in antiker und frühchrist cher Sicht. Medizinische Klinik 1964; 59:146-52.

32 See reference 31: 151-2.

33 Briau R. Chirurgie de Paul d'Égine. Paris: V Masson, 185 356-7.

34 See reference 27: 204-5.

35 See reference 33: 357 .

36 Temkin O. Hippocrates in a world of pagans and Christians. Bal@ more and London: The Johns Hopkins University Press, 1999 $249-56$.

\section{News and notes \\ Ethics and Genetics}

The International Programme in Bioethics Education and Research is organising the third Advanced European Bioethics Course, this time on Ethics and Genetics. The course will be held in Nijmegen, Holland from the 18 th to the 20th of November 1999.

Topics will include: Ethics and the human genome; genetic counselling; genetic screening; human gene therapy, and geneticisation.
For further information please contact: B Gordijn, PhD, Catholic University, Nijmegen, 232 Dept of Ethics, Philosophy and History of Medicine, PO box 9101, 6500 HB Nijmegen, Netherlands. Tel: 0031-243615320; fax: 0031-24-3540254; email: b.gordijn(a efg.kun.m; internet site: http://www.kun.nl./fmw/ onderwys/ukgene.htm 